Bangladesh J. Sci. Res. 29(2): 153-161, 2016 (December)

\title{
ARSENIC MOBILITY IN SALINE SOIL AND ITS IMPACT ON PLANT GROWTH
}

\author{
Sayeda Sabrina Ali ${ }^{1}$, Monira Begum, Muhammad Harunur Rashid \\ and S. M. Imamul Huq*
}

\section{Bangladesh Australia Centre for Environmental Research (BACER-DU), Department of Soil, Water and Environment, University of Dhaka, Dhaka-1000, Bangladesh}

\begin{abstract}
A study was conducted to investigate the mobility of arsenic in saline soil and its consequences on plant growth. Two different types of saline soils, $S_{1}(2.0 \mathrm{dS} / \mathrm{m})$ and $\mathrm{S}_{2}$ $(5.06 \mathrm{dS} / \mathrm{m})$, collected from the south-western part of Bangladesh were used for the experiment. There were two parts in the experiment, viz., in vitro incubation study and pot experiment. Arsenic at the rates of $0,0.05$ and $1.0 \mathrm{mg} / \mathrm{l}$ was applied to the soil with water and for plant as irrigation water. The soils under incubation were sequentially extracted with seven different extractants viz., distilled water, $1 \mathrm{M} \mathrm{NH}_{4} \mathrm{Cl}, 0.01 \mathrm{M} \mathrm{CaCl}_{2}$, 0.005M DTPA, 0.1M EDTA, $0.1 \mathrm{M} \mathrm{HCl}$ and $1 \mathrm{M} \mathrm{HCl}$. A local variety of rice, BRRI 41 was grown on the experimental soil as the test crop for pot experiment. The elevated arsenic concentration in the growth medium caused higher accumulation of arsenic as well as sodium in the plant.
\end{abstract}

Key words: Arsenic mobility, salinity, sodium, rice, plant growth

\section{Introduction}

The south-west coastal region of Bangladesh is prone to several types of disasters such as cyclones, tidal surges, floods, drought, salinity intrusions, repeated water-logging, and land subsidence. But impalpable disasters such as increased salinity and arsenic contamination affect local livelihoods and environments of this region. Out of 2.86 million hectares of coastal and offshore land about 1.06 million ha of arable land are affected by varying degrees of salinity (SRDI 2000) and further degradation will have detrimental consequences on food chain. Salinity damage to rice plants occurs as a result of excessive transport of $\mathrm{Na}^{+}$and $\mathrm{Cl}^{-}$to the shoots (Yeo et al. 1999). Salinity associated with excess sodium chloride adversely affects the growth and yield of plants by depressing the uptake of water and minerals and normal metabolism (Akhtar et al. 2001, Akram et al. 2001).Sodium chloride salts are quickly dissolved in water and play ionic effects in higher plant including rice crop (Nishimura et al. 2011). Excess $\mathrm{Na}^{+}$in plant cells directly damages membrane systems and organelles, resulting in plant growth reduction and abnormal development prior to plant death (Davenport et al. 2005, Quintero et al. 2007, Siringam et al. 2011).

The high level of arsenic in ground water of Bangadesh is geogenic in origin (Huq 2008). The development of strongly reducing conditions is believed to be responsible for the release of naturally occurring arsenic from the sediment into the ground water. Arsenite is the dominant form in flooded paddy soil (Takamatsu et al. 1982) which is considered to be the most toxic form. Upon

*Author for correspondence: <imamhuq@hotmail.com>. ${ }^{1}$ Present address: Department of Soil \& Environmental Sciences, University of Barisal, Barisal, Bangladesh. 
soil flooding during rice cultivation, arsenic in soil is mobilized, taken up by roots, and accumulated in the edible portion of the grains. Arsenic toxicity is responsible for shorter plant height, weaker tillering, thinner leaf coloring, earlier root coloring to yellowish brown or brown, and curled leaves under sunlight in rice plants (Yamane 1989). During the dry season ground water moves upward by capillary action and leaves arsenic in the soil. In addition, dry season aggravate salinity condition too. Moreover, it is found that As acts as soluble salts (Rabbi et al. 2007) which increases the possibility of being absorbed by plants instead of local soluble salts. Thus, a possible interaction between salinity and arsenic on rice grown on saline soil may exist. With this view in mind the present work was done to observe the effect of $\mathrm{Na}$ on As mobility in two saline soils of Bangladesh.

\section{Materials and Methods}

Soil samples were collected from four sampling sites of Khulna, a district situated in the southern part of the country. The soils belong to two representative soil series, namely Dumuria and Bajoa series. According to the USDA soil taxonomy all the series belong to Typic Endoaquepts subgroup (Ali et al. 2016). The georeferences of the sampling sites are presented in Table 1.

Both the soil series belong to 'Calcareous Grey' Soils of 'Ganges Tidal Floodplain' physiography. The soil samples were collected following the standard procedures (USDA 1951). The collected soil samples were air-dried, debris were removed and larger aggregates were ground by gently crushing with a wooden hammer. Then the ground samples were sieved by passing through a $0.5 \mathrm{~mm}$ and $5 \mathrm{~mm}$ stainless steel sieve for in vitro incubation experiment and pot experiments, respectively (Ali et al. 2016).

Table 1. GPS location of the soil samples.

\begin{tabular}{lllll}
\hline & \multicolumn{2}{l}{ Soils for Incubation experiment } & \multicolumn{2}{l}{ Soils for pot experiment } \\
\hline & $\mathrm{S}_{1}(2-4 \mathrm{dS} / \mathrm{m})$ & $\mathrm{S}_{2}(4-8 \mathrm{dS} / \mathrm{m})$ & $\mathrm{S}_{1}(2-4 \mathrm{dS} / \mathrm{m})$ & $\mathrm{S}_{2}(4-8 \mathrm{dS} / \mathrm{m})$ \\
GPS location & $22^{\circ} 48^{\prime} 50^{\prime \prime}$ and & $22^{\circ} 47^{\prime} 45^{\prime}$ and & $2^{\circ} 47^{\prime} 39.1^{\prime}$ and & $22^{\circ} 466^{\prime} 17.7^{\prime}$ and \\
& $89^{\circ} 29^{\prime} 32^{\prime}$ & $89^{\circ} 26^{\prime} 55^{\prime}$ & $8^{\circ} 27^{\prime} 30.3^{\prime}$ & $89^{\circ} 28^{\prime} 10.3^{\prime}$ \\
District & Khulna & Khulna & Khulna & Khulna \\
Soil series & Dumuria & Bajoa & Bajoa & Bajoa \\
Determined EC & 2.0 & 5.061 & 2.1 & 5.18 \\
Determined pH & 6.35 & 7.28 & 6.28 & 7.32 \\
\hline
\end{tabular}

\section{Experimental set-up}

Incubation experiment: The incubation experiment was carried out using the two types of saline soils. The detail of the experimental set up has been described in Ali et al. 2016. The extractability of $\mathrm{Na}$ and As of the soils were determined by sequential extraction process (Chowdhury et al. 2010). Seven different extractants were used in the extraction of the elements from the soils, viz. 
water soluble $\left(\mathrm{H}_{2} \mathrm{O}\right), \mathrm{NH}_{4} \mathrm{Cl}$ extractable (exchangeable) (Krishnamurti et al. 1995), $\mathrm{CaCl}_{2}$ extractable (exchangeable) (Ahnstom and Parker 1999), DTPA extractable (organically bound) (Lindsay and Norvell 1978), EDTA extractable (organically bound) (Lindsay and Norvell 1978), $0.1 \mathrm{M} \mathrm{HCl}$ extractable (CSTPA 1980) and 1M HCl (ANZEC 2000). Sodium content of the above mentioned samples were determined by flame photo analyzer (Huq and Alam 2005) and arsenic content by HG-AAS technique (Huq et al. 2008).

Pot experiment: The pot experiment was carried out in a net-house using air-dried soil in earthen pots. The detail of the experimental set-up has been described by Ali et al. 2016. The quality control/quality assurance (QC/QA) of the analyses was maintained following the standard procedure. Statistical analysis was done by using Microsoft Excel (2010) version.

\section{Results and Discussion}

Initial characteristics of the soil: Some common physical and chemical properties of soil samples were analyzed (Table 2) before the experiment, in order to know the initial status of the soil (Ali et al. 2016). In soil samples used for incubation experiment, both $\mathrm{Na}$ and As contents were higher in $S_{2}$ soil than $S_{1}$ soil while, for pot experiment, $S_{1}$ soil contained more As than $S_{2}$. This is because of the provenance of the experimental soil for the purpose. They were collected from a different spot in the saline area.

Table 2. Initial characteristics of soil.

\begin{tabular}{llllll}
\hline \multirow{2}{*}{$\begin{array}{l}\text { Soil } \\
\text { properties }\end{array}$} & \multicolumn{2}{c}{ Soils for incubation experiment } & & \multicolumn{2}{c}{ Soils for pot experiment } \\
\cline { 2 - 3 } \cline { 5 - 6 } $\mathrm{nH}$ & $\mathrm{S}_{1}$ & $\mathrm{~S}_{2}$ & & $\mathrm{~S}_{1}$ & $\mathrm{~S}_{2}$ \\
\hline $\mathrm{EC} \mathrm{(dS/m)}$ & 6.4 & 7.3 & & 6.3 & 7.3 \\
Available N (\%) & 2.0 & 5.1 & & 2.1 & 5.2 \\
Available P (mg/kg) & 0.16 & 0.12 & & 0.22 & 0.13 \\
Available K(me/100g) & 2.3 & 15.5 & & 7.7 & 9.6 \\
Available S (mg/kg) & 0.02 & 0.04 & & 0.03 & 0.1 \\
Soluble Na " & 337.4 & 558.4 & & 100.3 & 253.8 \\
Total As & 230.1 & 350.9 & & 121.8 & 270.3 \\
\hline
\end{tabular}

Interaction of As with $\mathrm{Na}$ in soil: Sequential extraction of the incubated soils by seven different extractants showed variation in the extractability of $\mathrm{Na}$ and As. This variation was due to different incubation period as well as to different extractants. Efficiency of the extractants can be observed by comparing the order of extractability of different extractants (Table 3). It can be seen that irrespective of soils and incubation periods, relative extractability of Na was higher. The nature of the extractants is supposed to give a better assessment of extractability of elements in soils. For example, $1 \mathrm{M} \mathrm{HCl}$ is likely to yield a higher value than $0.1 \mathrm{M} \mathrm{HCl}$ or any other 
extractants used in this experiment. However, $0.1 \mathrm{M} \mathrm{HCl}$ extracted more $\mathrm{Na}$ and As than any other extractants for any number of days of incubation (Fig. 1). On the other hand, the situation was quite different for DTPA which extracted the least (Fig. 2) amount of As and Na.

Table 3. Order of extractability of $\mathrm{Na}$ and As by extractants.

\begin{tabular}{|c|c|c|c|c|}
\hline \multirow{2}{*}{$\begin{array}{l}\text { Treatment } \\
\text { of arsenic }\end{array}$} & \multicolumn{4}{|c|}{ Soil type } \\
\hline & & $\mathrm{S}_{1}$ & & $\mathrm{~S}_{2}$ \\
\hline \multirow[t]{2}{*}{$\mathrm{As}_{0}$} & $\mathrm{Na}$ & $\begin{array}{l}0.1 \mathrm{M} \mathrm{HCl}>\mathrm{EDTA}>1 \mathrm{M} \mathrm{HCl}> \\
\mathrm{NH}_{4} \mathrm{Cl}>\mathrm{H}_{2} \mathrm{O}>\mathrm{CaCl}_{2}>\text { DTPA }\end{array}$ & $\mathrm{Na}$ & $\begin{array}{l}0.1 \mathrm{M} \mathrm{HCl}>1 \mathrm{M} \mathrm{HCl}>\mathrm{NH}_{4} \mathrm{Cl}>\mathrm{H}_{2} \mathrm{O}> \\
\text { EDTA }>\mathrm{CaCl}_{2}>\text { DTPA }\end{array}$ \\
\hline & As & $\begin{array}{l}1 \mathrm{M} \mathrm{HCl}>0.1 \mathrm{M} \mathrm{HCl}>\text { EDTA }> \\
\text { DTPA }>\mathrm{NH}_{4} \mathrm{Cl}>\mathrm{H}_{2} \mathrm{O}>\mathrm{CaCl}_{2}\end{array}$ & As & $\begin{array}{l}0.1 \mathrm{M} \mathrm{HCl}>1 \mathrm{M} \mathrm{HCl}>\text { EDTA }> \\
\text { DTPA }>\mathrm{NH}_{4} \mathrm{Cl}>\mathrm{H}_{2} \mathrm{O}>\mathrm{CaCl}_{2}\end{array}$ \\
\hline \multirow[t]{2}{*}{$\mathrm{As}_{0.05}$} & $\mathrm{Na}$ & $\begin{array}{l}0.1 \mathrm{M} \mathrm{HCl}>1 \mathrm{M} \mathrm{HCl}>\text { EDTA }> \\
\mathrm{NH}_{4} \mathrm{Cl}>\mathrm{H}_{2} \mathrm{O}>\mathrm{CaCl}_{2}>\text { DTPA }\end{array}$ & $\mathrm{Na}$ & $\begin{array}{l}0.1 \mathrm{M} \mathrm{HCl}>1 \mathrm{M} \mathrm{HCl}>\text { EDTA }> \\
\mathrm{NH}_{4} \mathrm{Cl}>\mathrm{H}_{2} \mathrm{O}>\mathrm{CaCl}_{2}>\text { DTPA }\end{array}$ \\
\hline & As & $\begin{array}{l}1 \mathrm{M} \mathrm{HCl}>0.1 \mathrm{M} \mathrm{HCl}>\text { EDTA }> \\
\mathrm{NH}_{4} \mathrm{Cl}>\mathrm{DTPA}>\mathrm{H}_{2} \mathrm{O}>\mathrm{CaCl}_{2}\end{array}$ & As & $\begin{array}{l}0.1 \mathrm{M} \mathrm{HCl}>1 \mathrm{M} \mathrm{HCl}>\text { EDTA }> \\
\mathrm{NH}_{4} \mathrm{Cl}>\mathrm{CaCl}_{2}>\text { DTPA }>\mathrm{H}_{2} \mathrm{O}\end{array}$ \\
\hline \multirow[t]{2}{*}{$\mathrm{As}_{1}$} & $\mathrm{Na}$ & $\begin{array}{l}0.1 \mathrm{M} \mathrm{HCl}>1 \mathrm{M} \mathrm{HCl}>\text { EDTA }> \\
\mathrm{NH}_{4} \mathrm{Cl}>\mathrm{H}_{2} \mathrm{O}>\mathrm{CaCl}_{2}>\text { DTPA }\end{array}$ & $\mathrm{Na}$ & $\begin{array}{l}0.1 \mathrm{M} \mathrm{HCl}>1 \mathrm{M} \mathrm{HCl}>\mathrm{NH}_{4} \mathrm{Cl}> \\
\text { EDTA }>\mathrm{H}_{2} \mathrm{O}>\mathrm{CaCl}_{2}>\text { DTPA }\end{array}$ \\
\hline & As & $\begin{array}{l}1 \mathrm{M} \mathrm{HCl}>0.1 \mathrm{M} \mathrm{HCl}>\mathrm{EDTA}> \\
\mathrm{NH}_{4} \mathrm{Cl}>\mathrm{DTPA}>\mathrm{H}_{2} \mathrm{O}>\mathrm{CaCl}_{2}\end{array}$ & As & $\begin{array}{l}0.1 \mathrm{M} \mathrm{HCl}>1 \mathrm{M} \mathrm{HCl}>\mathrm{NH}_{4} \mathrm{Cl}> \\
\text { EDTA }>\text { DTPA }>\mathrm{CaCl}_{2}>\mathrm{H}_{2} \mathrm{O}\end{array}$ \\
\hline
\end{tabular}

The matrix of $\mathrm{Na}$ and As extracted by $0.1 \mathrm{M} \mathrm{HCl}$ and DTPA are shown in Table 4 (a, b) and 5 (a, b) for two soils. It is found from the matrices that $0.1 \mathrm{M} \mathrm{HCl}$ extracted more $\mathrm{Na}$ and As from $\mathrm{S}_{2}$ soil than $\mathrm{S}_{1}$ soil. The values being 6,485 ppm for $\mathrm{Na}$ and $1.207 \mathrm{ppm}$ for As, both obtained at 60th day of incubation. The high efficiency of $0.1 \mathrm{M} \mathrm{HCl}$ for extraction of elements was also found by Kashem et al. (2007).

Extractability of Na in absence of As in $\mathrm{S}_{1}$ soil showed that the solubility of Na reduced at 60th day of incubation along with a sharp change from 30th day. Conversely, the condition was reverse for the extracted As. However, with the application of As in soil as treatment at a rate of 0.05 and $1 \mathrm{mg} / \mathrm{l}$ caused increasing extractabilities of Na with increasing content of As in soil. The situation was also similar for $S_{2}$ soil. The reason behind the phenomenon could be due to the fact that As in soil might form soluble complex with Na. Hence, addition of As can accentuate solubility of $\mathrm{Na}$ in soil as sodium arsenite $\left(\mathrm{NaAsO}_{2}\right)$. Moreover, it is found that the use of $0.1 \mathrm{M}$ $\mathrm{HCl}$ solution (CSTPA 1980) may reflect bioavailability of elements (Huq et al. 2008). It is thus expected that, there is a synergistic interaction between the two elements.

Similar trend was observed for $1 \mathrm{M} \mathrm{HCl}, \mathrm{NH}_{4} \mathrm{Cl}, \mathrm{H}_{2} \mathrm{O}$ and to some extent for DTPA. The unbuffered salt solutions like $\mathrm{NH}_{4} \mathrm{Cl}$ are able to release metals into solution which are associated with the exchange sites on the soil solid phase (Kashem et al. 2007, McLaughlin et al. 2000) which make them rapid and simple procedure to extract bioavailable metals (Kashem et al. 2007; Beckett 1989). On the other hand, in most cases EDTA showed a contrasting result. This could be 
due to the fact that the chelating agents, such as DTPA and EDTA, form complexes with free metal ions in solution and thus reduce the concentration of the free metal ions in solution (Kashem et al. 2007).

Table 4 (a). Matrix of $\mathrm{Na}$ and As for $\mathrm{S}_{1}$ soil extracted by $0.1 \mathrm{M} \mathrm{HCl}$.

\begin{tabular}{lccccccc}
\hline $\begin{array}{l}\text { Treatment } \\
\text { of As }\end{array}$ & \multicolumn{3}{c}{$\begin{array}{c}\text { Extractability of Na (ppm) at three } \\
\text { incubation days }\end{array}$} & & \multicolumn{3}{c}{$\begin{array}{c}\text { Extractability of As (ppm) at three } \\
\text { incubation days }\end{array}$} \\
\cline { 2 - 4 } \cline { 6 - 8 } & $\mathrm{T}_{0}$ & $\mathrm{~T}_{30}$ & $\mathrm{~T}_{60}$ & & $\mathrm{~T}_{0}$ & $\mathrm{~T}_{30}$ & $\mathrm{~T}_{60}$ \\
\hline $\mathrm{As}_{0}$ & 1155.74 & 1875.0 & 389.34 & & 0.0785 & 0.0275 & 0.4745 \\
$\mathrm{As}_{0.05}$ & 1278.69 & 1670.08 & 2182.38 & & 0.0822 & 0.0480 & 0.5110 \\
$\mathrm{As}_{1}$ & 1160.86 & 2643.44 & 2489.75 & & 0.1970 & 0.0430 & 0.5310 \\
\hline
\end{tabular}

Table 4 (b). Matrix of Na and As for $\mathrm{S}_{2}$ soil extracted by $0.1 \mathrm{M} \mathrm{HCl}$.

\begin{tabular}{lccccccc}
\hline \multirow{2}{*}{$\begin{array}{l}\text { Treatment } \\
\text { of As }\end{array}$} & \multicolumn{3}{c}{$\begin{array}{c}\text { Extractability of Na (ppm) at three } \\
\text { incubation days }\end{array}$} & & \multicolumn{3}{c}{$\begin{array}{c}\text { Extractability of As (ppm) at three } \\
\text { incubation days }\end{array}$} \\
\cline { 2 - 4 } \cline { 6 - 8 } & $\mathrm{T}_{0}$ & $\mathrm{~T}_{30}$ & $\mathrm{~T}_{60}$ & & $\mathrm{~T}_{0}$ & $\mathrm{~T}_{30}$ & $\mathrm{~T}_{60}$ \\
\hline $\mathrm{As}_{0}$ & 1027.66 & 2131.15 & 2028.69 & & 0.0915 & 0.2345 & 0.5670 \\
$\mathrm{As}_{0.05}$ & 1145.49 & 2182.38 & 1567.62 & & 0.2460 & 0.3622 & 0.7545 \\
$\mathrm{As}_{1}$ & 1242.83 & 2387.3 & 6485.66 & & 0.1160 & 0.3965 & 1.207 \\
\hline
\end{tabular}

Table 5 (a). Matrix of Na and As for $S_{1}$ soil extracted by DTPA.

\begin{tabular}{lcccccc}
\hline \multirow{2}{*}{$\begin{array}{l}\text { Treatment } \\
\text { of } A s\end{array}$} & \multicolumn{3}{c}{$\begin{array}{c}\text { Extractability of Na (ppm) at three } \\
\text { incubation days }\end{array}$} & \multicolumn{3}{c}{$\begin{array}{c}\text { Extractability of As (ppm) at three } \\
\text { incubation days }\end{array}$} \\
\cline { 2 - 7 } & $\mathrm{T}_{0}$ & $\mathrm{~T}_{30}$ & $\mathrm{~T}_{60}$ & $\mathrm{~T}_{0}$ & $\mathrm{~T}_{30}$ & $\mathrm{~T}_{60}$ \\
\hline $\mathrm{As}_{0}$ & 23.46 & 0.0 & 265.14 & 0.0333 & 0.0 & 0.0415 \\
$\mathrm{As}_{0.05}$ & 23.46 & 0.0 & 0.0 & 0.0545 & 0.0167 & 0.2280 \\
$\mathrm{As}_{1}$ & 28.55 & 0.0 & 0.0 & 0.1155 & 0.0 & 0.0912 \\
\hline
\end{tabular}

Table 5 (b). Matrix of Na and As for $S_{2}$ soil extracted by DTPA.

\begin{tabular}{lccccccc}
\hline $\begin{array}{l}\text { Treatment } \\
\text { of As }\end{array}$ & \multicolumn{3}{c}{$\begin{array}{c}\text { Extractability of Na (pm) at three } \\
\text { incubation days }\end{array}$} & & \multicolumn{3}{c}{$\begin{array}{c}\text { Extractability of As (ppm) at three } \\
\text { incubation days }\end{array}$} \\
\cline { 2 - 3 } \cline { 7 - 8 } & $\mathrm{T}_{0}$ & $\mathrm{~T}_{30}$ & $\mathrm{~T}_{60}$ & & $\mathrm{~T}_{0}$ & $\mathrm{~T}_{30}$ & $\mathrm{~T}_{60}$ \\
\hline $\mathrm{As}_{0}$ & 64.25 & 0.0 & 301.85 & & 0.1140 & 0.0 & 0.0980 \\
$\mathrm{As}_{0.05}$ & 13.26 & 0.0 & 0.0 & & 0.0667 & 0.0 & 0.0682 \\
$\mathrm{As}_{1}$ & 64.25 & 0.0 & 480.31 & & 0.0270 & 0.0 & 0.1110 \\
\hline
\end{tabular}

Accumulation of sodium ( $\mathrm{Na}$ ) in rice: Rice grown from this experiment showed significant accumulation of $\mathrm{Na}$ in plant root and stem (Table 6). Uptake was calculated by multiplying total 
concentration with dry matter production of plant. It is found from Table 6 that, distribution of $\mathrm{Na}$ within plant is not homogenous and accumulation of $\mathrm{Na}$ is the highest in roots than stem and grain. This result is supported by similar observation by Yamanouchi et al. (1987).

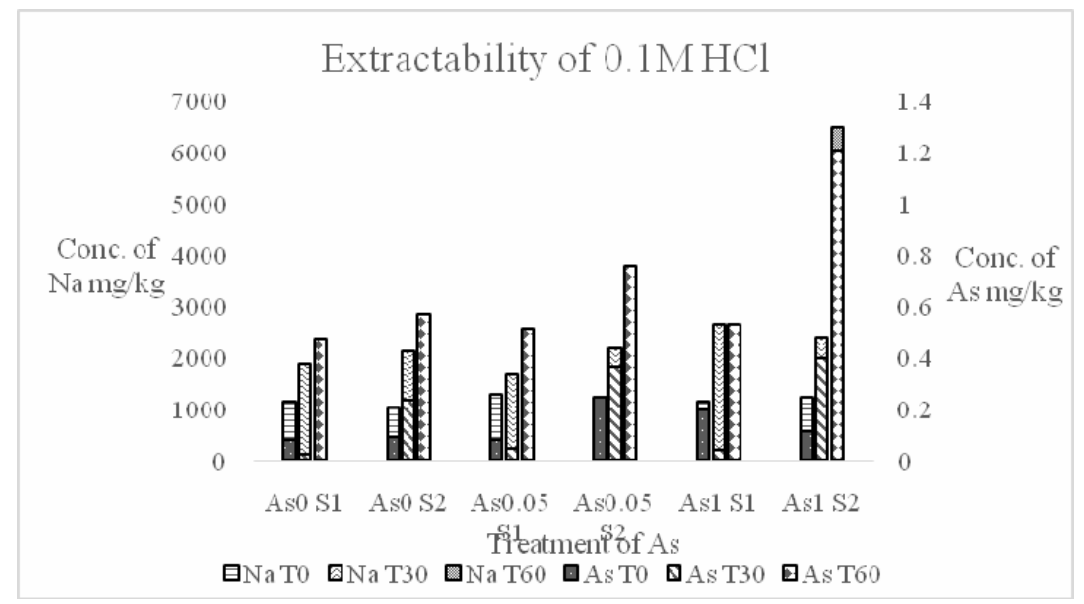

Fig. 1. Extractability of $0.1 \mathrm{M} \mathrm{HCl}$ for $\mathrm{S}_{1}$ and $\mathrm{S}_{2}$ soils for different As treatments.

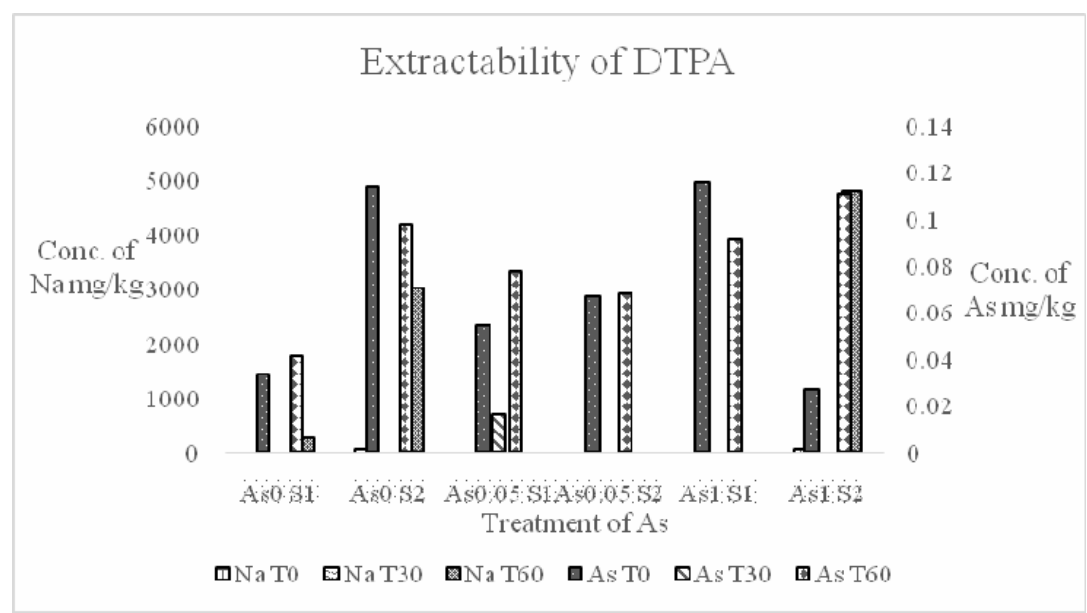

Fig. 2. Extractability of DTPA for $S_{1}$ and $S_{2}$ soils for different As treatments.

It is also observed from Table 6 that Na content in rice roots and stem increased with As treatments. Thus there might be a synergistic effect between $\mathrm{Na}$ and As in plant body. On the contrary, grain of rice had little or no $\mathrm{Na}$ and As. This observation corroborates with the results reported by Rabbi et al. (2007), which showed that grain of rice contains very little of As. Therefore, it is found that in arsenic treated soil, salinity appeared to have restricted the arsenic 
Table 6. Concentration and accumulation of $\mathrm{Na}$ in rice.

\begin{tabular}{|c|c|c|c|c|c|c|}
\hline \multirow{2}{*}{$\begin{array}{l}\text { As } \\
\text { treatment }\end{array}$} & \multicolumn{4}{|c|}{ Concentration of $\mathrm{Na}(\mathrm{mg} / \mathrm{kg})$} & \multirow{2}{*}{$\begin{array}{c}\text { Dry weight } \\
\text { of plant } \\
\text { (g/100 plants) }\end{array}$} & \multirow{2}{*}{$\begin{array}{c}\text { Accumulation } \\
\text { of Na (mg/100 } \\
\text { plants) }\end{array}$} \\
\hline & Root & Stem & Grain & Total plant & & \\
\hline $\mathrm{As}_{0}$ & 3438.98 & 862.77 & 0 & 4185.42 & 29.54 & 123.05 \\
\hline $\mathrm{As}_{0.05}$ & 3489.334 & 920.97 & 0 & 4386.28 & 163.6 & 717.60 \\
\hline $\mathrm{As}_{1}$ & 5122.987 & 723.91 & 318.56 & 6165.46 & 63.03 & 388.61 \\
\hline
\end{tabular}

Table 7. Correlation coefficient between $0.1 \mathrm{M} \mathrm{HCl}$ extracted Na of soil and Na content of plant.

\begin{tabular}{lll}
\hline $\mathrm{T}_{0}$ & Soil Na - Plant root Na & -0.4434 \\
& Soil Na - Plant stem Na & 0.7020 \\
& Soil Na - Plant grain Na & -0.4677 \\
$\mathrm{~T}_{30}$ & Soil Na - Plant root Na & $0.9742^{* *}$ \\
& Soil Na - Plant stem Na & $0.9959^{* * *}$ \\
& Soil Na - Plant grain Na & $0.9799^{* *}$ \\
$\mathrm{~T}_{60}$ & Soil Na - Plant root Na & 0.6332 \\
& Soil Na - Plant stem Na & 0.3364 \\
& Soil Na - Plant grain Na & 0.6127 \\
$\mathrm{~T}_{0}$ & Soil Na - Plant (root+stem) Na & -0.4112 \\
$\mathrm{~T}_{30}$ & Soil Na - Plant (root+stem) Na & 0.6612 \\
$\mathrm{~T}_{60}$ & Soil Na - Plant (root+stem) Na & $0.9653^{* *}$ \\
$\mathrm{~T}_{0}$ & Soil Na - Plant (root+stem+grain) Na & -0.4212 \\
$\mathrm{~T}_{30}$ & Soil Na - Plant (root+stem+grain) Na & $0.9899^{* *}$ \\
$\mathrm{~T}_{60}$ & Soil Na - Plant (root+stem+grain) Na & 0.6528 \\
\hline
\end{tabular}

accumulation in grain of rice. Besides the significant positive relationship between Na content of $0.1 \mathrm{M} \mathrm{HCl}$ extracted soil and $\mathrm{Na}$ content of plant suggests that $0.1 \mathrm{M} \mathrm{HCl}$ could be used to indicate the bioavailability of Na to rice (Table 7). The strong positive correlation indicates that increasing solubility of $\mathrm{Na}$ in soil can cause higher accumulation of $\mathrm{Na}$ in plant. Again, solubility of $\mathrm{Na}$ is a factor of availability of As in soil.

\section{Conclusion}

The results indicate a synergistic effect between $\mathrm{Na}$ and As which lead us to conclude that a high concentration of arsenic in the soil might augment the presence of $\mathrm{Na}$ in salt affected soils. Both salinity and arsenic affected plant growth. The higher was the arsenic concentration in soil, the higher was the solubility of $\mathrm{Na}$ in soil and consequently higher $\mathrm{Na}$ accumulation in plant. But grain of rice was free from both As and Na toxicity. The present study reveals a synergistic impact of As and $\mathrm{Na}$ on plant growth. Further studies are needed at field level to substantiate these observations. 


\section{Acknowledgement}

Authors gratefully acknowledge the technical assistance and laboratory facilities during the completion of this research work provided by the BACER (Bangladesh-Australia Center for Environmental Research).

\section{References}

Ahnstom, Z. S. and D. R. Parker. 1999. Development and Assessment of a Sequential Extraction Procedure for the Fractionation of Cadmium. Soil Science Society of American Journal 63: 1650-1658.

Akhtar, S., A. Wahid, M. Akram and E. Rasul. 2001. Effect of $\mathrm{NaCl}$ salinity on yield parameters of some sugarcane genotypes. International Journal Agriculture and Biology 3: 507-509.

Akram, M., M. Hussain, S. Akhtar and E. Rasul. 2001. Impact of $\mathrm{NaCl}$ salinity on yield components of some wheat accessions/varieties. International Journal Agriculture and Biology 4:156-158.

Ali, S. S., M. Begum and S.M.I. Huq. 2016. Plant growth as affected by concomitant movement of arsenic and sulphur in saline soils. Open Journal of Soil Science 6: 59-67.

ANZECC. 2000. Australian and New Zealand Environment and Conservation Council (ANZECC) and Agriculture and Resource Management Council of Australia and New Zealand (ARMCANZ). Australian and New Zealand Guidelines for Fresh and Marine Water Quality. ANZEC and ARMCANZ, Canberra, 1-103.

Beckett, P.H.T. 1989. The use of extractants in studies on trace metals in soils, sewage sludges and sludgetreated soils. Advance Soil Science 9: 143-176.

Chowdhury, M.T.A., L. Nesa, M.A. Kashem, S.M.I. Huq. 2010. Assessment of the phyto availability of Cd, $\mathrm{Pb}$ and $\mathrm{Zn}$ using various extraction procedures. Pedologist 53(3): 80- 95.

CSTPA. 1980. Handbook on reference methods for soil testing. Council on Soil Testing and Plant Analysis. University Georgia, Athens, Georgia, USA.

Davenport, R., R. A. James, A. Zakrisson-Plogander, M.Tester and R.Munns. 2005. Control of sodium transport in durum wheat. Plant Physiology 137: 807-818.

Huq, S. M. I. 2008. Fate of arsenic in irrigation water and its potential impact on the food chain. In: Arsenic contamination of groundwater: mechanism, analysis and remediation. pp. 23-24. John Wiley \& Sons, Inc., Hoboken, New Jersey.

Huq, S. M. I. and M. D. Alam. 2005. A Handbook on Analyses of Soil, Plant, and Water. BACER-DU, pp.xxii-246. University of Dhaka, Bangladesh.

Huq, S. M. I., A. F. M. M. Hoque, J. C. Joardar and J.U. Shoaib. 2008. Arsenic movement in some profiles of Bangladesh soils. SENRA academic publishers, Burnaby. British Columbia 2(1): 251-259.

Kashem, M. A., B.R. Singh, T. Kondo, S. M. I. Huq and S. Kawai. 2007. Comparison of extractability of Cd, $\mathrm{Cu}, \mathrm{Pb}$ and $\mathrm{Zn}$ with sequential extraction in contaminated and non-contaminated soils. International Journal of Environmental Science and Technology 4(2): 169-176.

Krishnamurti, G.S.R., P.M. Huang, K.C.J. Van Rees, L.M. Kozak and H.P.W. Rostead. 1995. A new soil test method for determination of plant available cadmium in soils. Communications in Soil Science Plant Analysis 26(17-18): 2857-2867.

Lindsay, W.L. and W.A. Norvell. 1978. Development of DTPA soil test for zinc, iron, manganese, and copper. Soil Science Society of America Journal 42: 421-428. 
McLaughlin, M.J., B.A. Zarcinas, D.P. Stevens and N. Cook. 2000. Soil testing for heavy metals. Communications in Soil Science Plant Analysis 31(11-14): 1661-1700.

Nishimura, T.S., Cha-um, M. Takagaki and K. Ohyama. 2011. Survival percentage, photosynthetic ability and growth characters of two indica rice (Oryza sativa L. spp. indica) cultivars in response to isosmotic stress. Spanish Journal of Agricultural Research 9: 262-270.

Quintero, J.M., J.M. Fournier and M. Benlloch. 2007. $\mathrm{Na}^{+}$accumulation in shoot is related to water transport in $\mathrm{K}^{+}$-starved sunflower plants but not in plants with anormal $\mathrm{K}^{+}$status. J. Plant Physiology 164: 60-67.

Rabbi, S.M. F., A. Rahman, M.S. Islam, K.Q. Kibria and S.M.I. Huq. 2007. Arsenic uptake by rice (Oryza sativa L.) in relation to salinity and calcareousness in some saline soils of Bangladesh. Dhaka University Journal of Biological Science 16(1): 29-39.

SRDI. 2000. Soil Resource and Development Institute. Salinity status of Bangladesh. pp. 8-20.

Siringam, K., N.S. Juntawong, Cha-um and C. Kirdmanee. 2011. Salt stress induced ion accumulation, ion homeostasis, membrane injury and sugar contents in salt-sensitive rice (Oryza sativa L. spp. indica) roots under isoosmotic conditions. African Journal of Biotechnology 10: 1340-1346.

Takamatsu, T.H., Aoki and T. Yoshida. 1982. Determination of arsenate, arsenite, monomethyl arsonate and dimethyl arsinate in soil polluted with arsenic. Soil Science 133: 239-246.

USDA. 1951. Soil Survey Manual. Soil Survey Staff, Bureau of Plant Industry, Soils and Agricultural Engineering, United States Department of Agriculture, Washington. Handbook no. 18, 205.

Yamane, T. 1989. The mechanisms and countermeasures of arsenic toxicity to rice plant. Bulletin of Shimane Agricultural Experiment Station 24: 1-95.

Yamanouchi, M., Y. Maheda and T. Nagai. 1987. Relationships between varietal differences in salt tolerance and characteristics of sodium adsorption and translocation in rice. Japanese Journal of Soil Science and Plant Nutrition 58: 591-594.

Yeo, A.R., S.A. Flowers, G. Rao, N. Welfare, Senanayake and T.J. Flowers. 1999. Silicon reduces sodium uptake in rice (Oryza sativa L.) in saline conditions and this is accounted for by a reduction in the transpirational bypass flow. Plant, Cell and Environment 22: 559-565.

(Manuscript received on 9 November, 2016; revised on 21 December, 2016) 